alsinflyat
JURNAL PENELITIAN BAHASA, SASTRA, DAN

BUDAYA ARAB

P-ISSN: 2615-7241 | E-ISSN: 2721-480X // Vol. 3 No. 2 | 154-166

(-) https://ejournal.upi.edu/index.php/alsuniyat/index

\title{
Pendekatan Saintifik Kurikulum 2013 dalam Pembelajaran Bahasa Arab bagi Siswa Tunanetra
}

\author{
Yunita Laila Zulfa \\ Universitas Islam Negeri Sunan Kalijaga Yogyakarta, Indonesia \\ E-mail: yunitalailazulfa@upi.edu
}

\begin{abstract}
:
This study aimed to describe the implementation of Arabic learning for the visually impaired using the scientific approach. This research is descriptive qualitative research with Miles and Huberman model data analysis and data validity test using data triangulation. The implementation of the scientific approach for the visually impaired in MTs. Yayasan Kesejahteraan Tunanetra is different in the observing section. Students cannot make observations with the sense of sight, so observations cannot deal with video media. Students more often make observations with the sense of hearing with, listen to explanations, and use the sense of touch for media used only with braille. However, unfortunate is very minimal textbooks that form a Braille so that students cannot learn independently.
\end{abstract}

Keywords:

Arabic; Learning; Curriculum 2013; Blind

\begin{abstract}
Abstrak:
Tujuan penelitian ini untuk mendiskripsikan pelaksanaan pembelajaran bahasa Arab bagi tunanetra dengan pendekatan saintifik. Penelitian ini penelitian deskriptif kualitatif dengan analisis data model miles and huberment dan uji keabsahan data menggunakan triangulasi data. Implementasi pendekatan saintifik bagi tunanetra di MTs. Yayasan Kesejahteraan Tunanetra berbeda dibagian mengamati peserta didik tidak bisa melakukan pengamatan dengan indra penglihat. Peserta didik melakukan pengamatan dengan indra pendengaran dengan mendengarkan penjelasan dan meraba. Untuk media yang digunakan juga hanya dengan huruf braille. Tetapi yang disayangkan tidak ada buku ajar yang berbentuk braille sehingga peserta didik tidak bisa belajar mandiri.
\end{abstract}

Keywords:

Bahasa Arab; Pembelajaran; Kurikulum 2013; Tunanetra

\section{PENDAHULUAN}

Pendidikan merupakan hak semua warga negara Indonesia, dengan pendidikan seseorang bisa mendapatkan masa depan yang lebih baik dan bisa memandang masa depan dengan lebih cerah. Indonesia sekarang sedang menggerakkan perbaikan di berbagai sektor untuk mewujudkan Indonesia maju, salah satu wujudnya adalah diwajibkannya anak-anak Indonesia sekolah sampai jenjang Sekolah Lanjut Tinggi Atas (SLTA). Implementasi kebijakan pemerintah tersebut diwujudkannya dengan Bantuan Operasional Sekolah untuk membantu pembiayaan kemajuan dan mutu sekolah anak-anak Indonesia (Muryati, 2016). 
Selain itu, untuk menunjang Indonesia maju dari beberapa kementerian menggalakkan beasiswa kepada putra putri Indonesia sebagai penerus masa depan bangsa. Program ini sangat bagus. Karena seperti yang sudah menjadi statement umum bahwa "bangsa yang maju bukan bangsa yang memiliki sumber daya alam melimpah tapi bangsa yang maju adalah bangsa yang memilik sumber daya manusia yang berkualitas". Lagi-lagi salah satu cara memperbaiki SDM adalah dengan Pendidikan (Muhardi, 2004).

Kebijakan ini sungguh sangat indah jika bisa terealisasikan secara merata di Indonesia. Tetapi kenyataannya, Indonesia masih belum ramah bagi para disabilitas. Perlu perhatian khusus dan tindakan khusus untuk para disabilitas hingga mereka bisa hidup mandiri dan normal seperti manusia normal lainnya. Sebuah penelitian di kota Malang tentang aksebilitas bagi disabilitas masih sangat kurang aksesibel. Dari segi sarana tempat parkir di seluruh kota Malang tidak ada tempat parkir khusus bagi para disabilitas (Thohari, 2014) masih sangat minim dan jauh dari standar, ini sebagai cerminan kurang diperhatikannya para disabilitas salah satunya penyandang tunanetra.

Kurikulum 2013 merupakan kurikulum yang dikeluarkan Kementerian Pendidikan sebagai kurikulum yang bisa membawa angin segar bagi dunia pendidikan di Indonesia. Kurikulum akan bisa berhasil jika implementasi dan penerapannya sesuai dengan petunjuk dan benar. Data menunjukkan fasilitas sarana bagi tunanetra masih belum terealisasikan secara merata. Data tersebut menggugah peneliti untuk meneliti pembelajaran bahasa Arab di MTs. Yaketunis sebagai salah satu bentuk partisipasi peneliti untuk mengangkat siswa tunanetra di dunia pendidikan.

Kurikulum 2013 yang mengusung pembelajaran dengan pendekatan saintifik diharapkan bisa merubah pembelajaran di Indonesia menjadi lebih baik. Perubahan yang diharapkan juga bisa merata tidak terkecuali kepada peserta didik tunanetra. Hubungan tujuan perubahan pembelajaran yang lebih baik dengan pendekatan saintifik Kurikulum 2013 dan data yang menunjukkan kurangnya pendidikan bagi tunanetra di Indonesia membuat peneliti ingin mendeskripsikan fenomena pembelajaran bahasa Arab bagi tunanetra dengan pendekatan saintifik.

Pendekatan saintifik diadopsi dari aktifitas proses sains sebagaimana ilmuwan sains melakukan penelitian. Pembelajaran mengarahkan peserta didik untuk mencari tahu bukan guru yang memberi pengetahuan. Peserta didik sebagai subjek dalam pembelajaran sehingga peserta 
didik yang aktif untuk mencari tahu. Guru dalam pendekatan saintifik menjadi fasilitator bagi peserta didik untuk mencari pengetahuan dan belajar (Majid \& Rochman, 2015).

Karakteristik pendekatan saintifik adalah: 1) Pembelajaran berpusat pada peserta didik; 2) Melibatkan keterampilan proses sains dalam pembelajaran; 3) Melibatkan proses kognitif yang potensial dalam merangsang perkembangan intelektual, khususnya keterampilan berpikir tingkat tinggi; 4) Pembelajaran yang dapat mengembangkan karakter peserta didik (Hosnan, 2014). Karakter yang sudah disebutkan tersebut bisa membantu peserta didik mengembangkan pengetahuan, keterampilan dan sikap peserta didik. Peserta didik menjadi subjek pembelajaran dan diberi kebebasan mencari sendiri pengetahuan ini akan membentuk sikap mandiri, disiplin dan bertanggung jawab.

Aktifitas pembelajaran bahasa Arab dengan pendekatan saintifik memiliki lima tahap yaitu pertama mengamati dilakukan dengan indra yang dimiliki manusia bisa dengan mata atau melihat, mengamati dan membaca, dengan pendengaran atau mendengarkan atau menyimak. Tahap yang kedua yaitu menanya selanjutnya mengumpulkan data, ketiga yaitu mencoba, kegiatan keempat mengasosiasi dan yang terakhir mengkomunikasikan.

Peserta didik tunanetra adalah anak memiliki gangguan pada indra penglihatan sehingga diperlukan layanan khusus dalam proses pembelajaran dan kehidupan. Sebenarnya peserta didik tunanetra tidak terlalu beda jauh dengan peserta didik normal. Semua organ tubuh dan indra yang dimiliki masih berfungsi kecuali indra penglihatan dan mata saja (Harimi, 2018).

Terdapat beberapa penelitian terdahulu yang meneliti tunanetra salah satunya penelitian tentang pengembangan media pembelajaran bahasa isyarat dengan peragaan tangan untuk mendiskripsikan posisi lidah untuk mengucapkan makhārijul hurūf hijaiah. Dengan hasil media ini efektif untuk meningkatkan ketepatan pelafalan makhārijul hurūf hijaiah dalam membaca AlQur'an bagi tunanetra (Adriyanto dkk., 2018). Selain penelitan tersebut ada juga penelitian yang membahas tahapan yang dilakukan peserta didik tunanetra untuk belajar membaca huruf hijaiyah, membaca tulisan Arab braille, hingga bisa membaca Al-Qur'an braille (Rubini \& Setyawan, 2019). Pengembangan implementasi pendekatan saintifik dalam pembelajaran mahārah qira'ah pelajaran bahasa Arab kurikulum 2013 juga pernah diteliti, penelitian ini membahas langkahlangkah pembelajaran mahārah qira'ah dengan pendekatan saintifik (Rathomi, 2019).

Vol. 3 No. 2 | 154-166

AISUNIYAT, p-ISSN: 2615-7241, e-ISSN: 2721-480X 
Berbeda dengan penelitian ini, penelitian ini meneliti tentang pembelajaran bahasa Arab bagi tunanetra dengan pendekatan saintifik Kurikulum 2013 yang diimplementasikan di MTs. Yaketunis (Yayasan Kesejahteraan Tunanetra) Yogyakarta. Penelitian ini mendeskripsikan tahapan, fenomena pembelajaran bahasa Arab bagi tunanetra dengan pendekatan saintifik serta faktor yang mendukung dan menghambat jalannya implementasi pendekatan saintifik bagi tunanetra di MTs. Yaketunis Yogyakarta.

\section{METODE}

Pendekatan penelitian ini adalah kualitatif dengan jenis penelitian deskriptif untuk menggambarkan secara rinci pelaksanaan pembelajaran bahasa Arab dengan pendekatan saintifik bagi siswa tunanetra. Pengumpulan data dilakukan dengan observasi, wawancara dan dokumentasi. Observasi dilakukan untuk mengamati rangkaian pembelajaran bahasa Arab yang di kelas.

Wawancara untuk mengumpulkan data tentang pembelajaran bahasa Arab dengan pendekatan saintifik bagi tunanetra dan faktor-faktor yang menghambat pembelajaran bahasa Arab dari guru bahasa Arab yang mengajar, peserta didik dan kepala sekolah. Dokumentasi digunakan untuk memperkuat data yang diambil dari observasi dan wawancara, dokumentasi ini pengambilan dokumen berupa RPP (Rencana Pelaksaan Pembelajaran) yang dbuat oleh guru bahasa Arab, silabus dan buku ajar yang digunakan.

\section{Bagan analisis data}

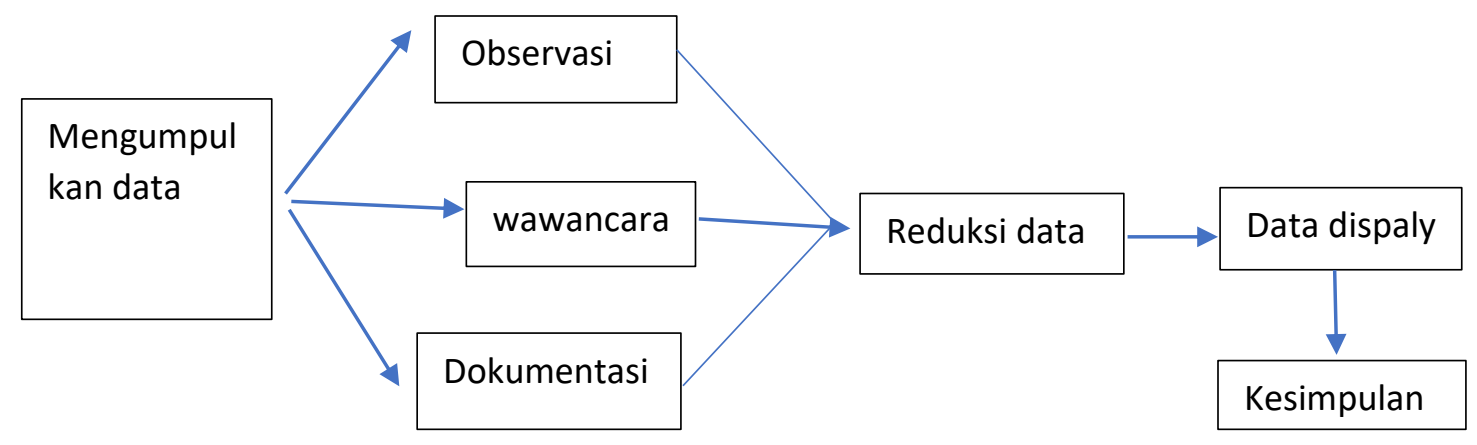

Analisis data yang digunakan dalam penelitian ini adalah model Miles and Huberment. Aktifitas dalam analisi data adalah pertama pengumpulan data dari lapangan. Kegiatan kedua yaitu reduksi data, seluruh data yang didapatkan dari observasi, wawancara, dan dokumentasi dipilih dengan teliti dan cermat data-data yang penting. Kegiatan yang ketiga yaitu data display 
ALSUNIYAT: Jurnal Penelitian Bahasa, Sastra, dan Budaya Arab

atau penyajian data dari data yang sudah dipilih dan difokuskan maka perlu disajikan dengan baik dan sesuai urutan. Dan yang terakhir adalah penarikan kesimpulan atas data-data yang telah disajikan.

\section{HASIL DAN PEMBAHASAN}

Berdasarkan dari observasi, wawancara, dan dokumentasi implementasi pendekatan saintifik dalam pembelajaran bahasa Arab Kurikulum 2013 bagi siswa tunanetra di Madrasah Tsanawiyah Yayasan Kesejahteraan Tunanetra sesuai standar proses Kurikulum 2013. Ada tiga tahapan dalam proses pembelajaran yaitu perencanaan, pelaksanaan, dan evaluasi pembelajaran. Tapi penelitian ini hanya akan membahasa perencanaan dan pelaksanaan pembelajaran karena implementasi pendekatan saintifik muncul di dua unsur tersebut.

RPP (Rencana Pelaksanaan Pembelajaran) guru untuk mengajar peserta didik menjabarkan bahwa model pembelajaran yang digunakan yaitu saintifik, pengamatan, tanya jawab dan diskusi kelas. Implementasi pendekatan saintifik bagi siswa tunanetra dalam RPP sangat ketara di kegiatan inti pembelajaran. Kegiatan inti ini menjabarkan runtutan pembelajaran dari peserta didik melakukan pengamatan tentang materi, selanjutkan peserta didik diberi kesempatan untuk bertanya materi yang sudah disajikan, kegiatan ketiga yaitu mengekspolasi yaitu peserta didik diberi waktu untuk berdiskusi dengan teman dan guru, kegiatan keempat yaitu mengasosiasi siswa diberi kesempatan mengolah data yang telah didapat dan yang terakhir adalah mencipta dan mengkomunikasikan.

Pelaksanaan pembelajaran adalah kegiatan dimana guru melakukan interaksi belajar mengajar dengan pedoman pada Rancangan Pelaksanaan Pembelajaran yang sudah dibuat oleh guru. Sebelum melaksanakan interaksi belajar-mengajar, guru melakukan pemanasan dulu yang dituangkan dalam kegiatan pembuka. Kegiatan pembukaan bertujuan untuk menarik perhatian peserta didik, menumbuhkan motivasi belajar dan memberi pengantar atau rambu-rambu tentang pembelajaran yang akan dilakukan.

Kegiatan pembukaan, guru membuka pelajaran dengan menyiapkan psikis dan spiritual peserta didik yaitu diawali dengan doa dan absen untuk memperlihatkan bahwa guru peduli dengan peserta didik. Pada kegiatan pembukaan guru juga sedikit menyinggung materi yang sudah lewat bertujuan memberi stimulus kepada peserta didik agar bisa ingat kembali pelajaran yang

Vol. 3 No. 2 | 154-166

AISUNIYAT, p-ISSN: 2615-7241, e-ISSN: 2721-480X 
ALSUNIYAT: Jurnal Penelitian Bahasa, Sastra, dan Budaya Arab

sudah lewat. Setelah peserta didik ingat guru memberi penjelasan sedikit materi yang akan dipelajari hari ini dan tujuan mempelajarinya.

Prinsip pembelajaran bahasa Arab yang digunakan oleh guru adalah pembelajaran senang. Ini dilihat dari hasil wawancara, banyak peserta didik yang mengatakan bahwa suka dengan pelajaran karena pembelajarannya menyenangkan dan santai. Selain dari peserta didik guru juga mengungkapkan bahwa setiap sebelum pembelajaran guru selalu melihat dulu kondisi kelas dan peserta didik apakah sedang keadaan senang atau tidak. Pernyataan ini juga didukung dengan observasi dimana dalam pembelajaran bahasa Arab dimasukkan permainan sehingga pembelajaran lebih santai dan menyenangkan.

Kegiatan inti pembelajaran, di sini letak pendekatan saintifik diimplementasikan. Pada kegiatan inti proses pebelajaran dengan pendekatan saintifik terdapat lima langkah yaitu Mengamati, Menanya, Mencoba, Menalar, Mengkomunikasikan.

\section{Mengamati}

Pengamatan dituliskan dalam RPP dengan kegiatan mengamati, menyimak pelafalan kata, frasa dan kalimat bahasa Arab atau bacaan teks yang diperdengarkan atau dibacakan oleh guru, kegiatan kedua siswa menirukan pelafalan kata, kegiatan ketiga mencermati kata, frasa dan kalimat atau teks bahasa Arab yang diperdengarkan. Kegiatan mengamati dilakukan dengan meminta peserta didik mengingat dan membayangkan tentang materi yang akan dipelajari.

Jika materi tentang mufradāt, guru meminta salah satu peserta didik untuk membacakan mufradāt yang sudah dipelajari minggu lalu dari catatan peserta didik berupa braille, peserta lain mendengarkan. Untuk mengetahui ingatan peserta didik, guru sedikit memberi permainan sehingga peserta didik tidak bosan dan menjadikan suasana belajar menyenangkan.

Salah satu permainan yang dimainkan guru adalah seluruh peserta didik diminta berdiri, kemudian satu orang ditunjuk guru untuk menyebutkan satu mufradāt yang minggu lalu dipelajari. Kemudian yang sudah berhasil menyebutkan mufradāt boleh duduk dan menunjuk satu teman untuk menyebutkan mufradāt. Bagi peseta didik yang tidak bisa menyebutkan mufradāt dihukum menulis dua mufradāt.

Menurut Abdal Chaqil menjelaskan pada dasarnya pembelajaran bahasa Arab bagi tunanetra tidak beda jauh degan siswa normal. Tetapi guru perlu melakukan memodifikasi 
pembelajaran sesuai kebutuhan tunanetra (Harimi, 2018). Ini sesuai dengan yang peneliti dapatkan di lapangan dalam implementasi pendekatan saintifik perbedaan yang sangat mencolok dengan peserta didik tunanetra pada kegiatan mengamati. Guru harus memodifikasi pembelajaran pengamatan tidak menggunakan indra penglihatan tapi memaksimalkan indra lain yang berfungsi dengan baik.

Menurut A. Machin kegiatan mengamati hendaklah dibuka seluas-luasnya peserta didik diberi kesempatan yang bervariasi seperti kegiatan membaca, mendengar, melihat, dan menyimak. Guru memberi kesempatan kepada peserta didik untuk mengamati dan memperhatikan hal penting objek yang akan dikaji (Machin, 2014). Kegiatan pengamatan untuk peserta didik tunanetra dilakukan dengan mendengarkan, membaca buku berbentuk braille (meraba) tidak bisa menggunakan indra penglihatan untuk mengamati objek yang dikaji. Dalam pelaksanaan sebenarnya masih ada indra pencium dan perasa yang bisa digunakan tetapi kurang efektif digunakan untuk belajar bahasa.

Media yang digunakan untuk kegiatan mengamati dengan audio, guru sendiri, buku kosong dan alat tulis braille. Menurut Saputri guru mengajar peserta didik tunanetra lebih detail dan rinci dalam menjelaaskan materi sehingga peserta didik memiliki bayangan tentang materi (Saputri, 2013). Buku braille merupakan bahan ajar yang sangat dibutuhkan dalam pembelajaran tetapi masih belum ada bahan ajar yang bisa digunakan untuk belajar secara mandiri peserta didik di MTs. Yaketunis.

\section{Menanya}

Kegiatan kedua yaitu menanya pada kegiatan ini bertujuan agar peserta didik memberi tanggapan verbal dari materi yang sudah diamati sehingga mengembangkan berpikir kritis, kreatif, rasa ingin tahu dan mampu merumuskan pertanyaan yang berguna bagi perkembangan kehidupan sehari-hari peserta didik (Budiyanto dkk., 2016). Kegiatan menanya dalam kegiatan pembelajaran bahasa Arab bagi tunanetra di MTs. Yaketunis diimplementasikan dengan guru memotivasi peserta didik agar bertanya atau sebaliknya guru memberi pertanyaan kepada peserta didik sehingga guru mendapat respon verbal dari peserta didik tentang materi yang dipelajari.

Kegiatan menanya ini diberikan kepada peserta didik seluas-luasnya, setiap masih dalam pembelajaran bahasa Arab peserta didik dipersilahkan guru untuk bertanya. Seperti saat 
pembelajaran pada kegiatan mencoba peserta didik ada kesulitan maka peserta didik boleh bertanya. Jadi untuk menanya guru memberikan waktu bebas selama peserta didik perlu bertanya guru mempersilahkan.

\section{Mencoba/mengumpulkan data}

Mencoba atau mengumpulkan data merupakan kegiatan eksperimen atau mengumpulkan data tentang materi yang diuji (Budiyanto dkk., 2016; Machin, 2014). Kegiatan mencoba yang dipraktikkan guru di Mts. Yaketunis prinsip semangat. Semangat peserta didik bisa membantu kelancaran pembelajaran. Kegiatan mencoba dilakukan dengan kelompok dan mendiri tergantung mahārah yang akan dipelajari. Mahārah kalām seperti hiwār dilakukan percobaan dengan kelompok atau berpasangan. Sedangkan mahārah kitābah dengan individu. Kegiatan mencoba jika perlu dilakukan berulang-ulang sehingga peserta didik bisa merasakan pembelajaran yang nyata.

Selain mencoba, pada kegiatan ketiga guru melakukan variasi dengan meletakkan kegiatan mengumpulkan data/eksplorasi agar peserta didik tidak bosan dengan pemebelajaran. Pengumpulan data ini dilakukan dengan mendiskusikan isi bacaan teks, mendiskusikan tata bahasa yang ada dalam teks dan mengidentifikasi sifat-sifat terpuji dan hikmah yang terkandung di dalam teks. Dalam kegiatan mencoba dan mengumpulkan data dilakukan secara individual dan terkadang kelompok disesuaikan dengan materi pelajaran. Seperti jika materinya percakapan maka kegiatannya dilakukan dega kelompok. Tapi sayangnya tidak ada buku ajar berbentuk braille membuat peserta didik terbatas untuk mencari informasi yang lebih banyak.

\section{Menalar}

Menalar dan mengasosiasikan informasi yang didapat. Kegiatan ini mengasah kemampuan mengelompokkan ide, mengaitkan informasi yang menguatkan hingga bertentangan dari beragam sumber, kejadian, pengamatan, eksperimen, sehingga menjadi pengalaman memori (Machin, 2014). Setelah peserta didik mendapat banyak informasi materi dari pengamatan dan bertanya peserta didik diberi kesempatan untuk mengasosiasikan informasi yang sudah didapat sehingga bisa menjadi pengalaman memori yang tersimpan rapi.

Kegiatan menalar ini dilakukan peserta didik tunanetra dengan memantapkan pemahaman kalimat yang telah dipelajari dan sudah bisa menggunakan kalimat tersebut 
ALSUNIYAT: Jurnal Penelitian Bahasa, Sastra, dan Budaya Arab

sebagai ungkapan. Peserta didik juga sudah bisa menyimpulkan isi dari pelajaran yang telah dipelajari dengan bisa menyimpulkan bacaan teks, percakapan, dan unsur struktur bahasa Arab yang digunakan. Untuk melihat tingkat kepahaman peserta didik pada kegiatan menalar ini guru memberi tugas mencipta seperti membuat kalimat dengan kosakata yang dipelajari, dan peserta didik sudah menggunakan tata bahasa sesuai yang sudah diajarkan seperti penggunaan mubtada' dan khabar.

\section{Mengkomunikasikan}

Pada tahap terakhir kegiatan pembelajaran, peserta didik mempresentasikan hasilnya. Mengkomunikasikan ini juga mengasah tanggung jawab, percaya diri dan kedisiplinan peserta didik. Kegiatan mengkomunikasikan bisa berbentuk tulisan dan presentasi atau menceritakan hasil belajar peserta didik (Budiyanto dkk., 2016; Machin, 2014). Kegiatan mengkomunikasikan siswa tunanetra di MTs. Yaketunis dilakukan dengan mempresentasikan hasil ciptaan atau menyimpulkan hasil belajar.

Salah satu kegiatan mengkomunikasikan untuk tunanetra dilakukan dengan membuat kalimat sederhana dengan struktur susunan mubtada' khabar muqaddam dan mubtada' muakhar kemudian di presentasikan hasilnya di depan kelas. Kegiatan mengkomunikasikan dilakukan dengan praktek percakapan bahasa Arab. Serta dengan mempresentasikan hasil karya cipta atau simpulan dari pelajaran yang telah dipelajari. Media tulis yang diguanakan adalah tulisan arab braille.

Bagan implementasi pendekatan saintifik pembelajaran bahasa Arab bagi tunanetra

\section{MENGAMATI}

mendengarkan dengan cermat bacaan, penjelasan guru atau teman.

MENANYA
$\begin{aligned} & \text { Guru memotivasi peserta didik untuk bertanya terkadang guru memberi pertanyaan } \\ & \text { untuk memberi stimulus kepada peserta didik. Kegiatan bertanya diberikan seluas- } \\ & \text { luasnya oleh guru kepada peserta didik selama pembelajaran bahasa Arab } \\ & \text { berlangsung. Jadi peserta didik tidak tertekan hanya pada satu kesempatan. }\end{aligned}$

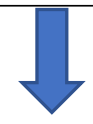

Vol. 3 No. 2 | 154-166

AISUNIYAT, p-ISSN: 2615-7241, e-ISSN: 2721-480X 


\section{MENCOBA/MENGEKSPOLASI/MENGUMPULKAN DATA}

Peserta didik berdiskusi dengan teman tentang materi yang dipelajari, kekurangan sumber belajar membuat peserta didik tunanetra kekurangan sumber untuk mencari informasi. Mencoba dilakukan dengan m-nciba merangkai kalimat dari bahasa Arab dengan tata bahasa tertentu seperti Mub $d a^{\prime}$ dan Khabar.

\section{MENALAR/MENGASOSIASI}

Peserta didik menyimpulkan materi yang sudah dipelajari dan bisa menciptakan dari pelajaran yang sudah dipelajari. Seperti sudah bisa bercakap-cakap dengan bahasa Arab. Bisa membuat kalimat dengan susunan mubtada' dan khabar. Dan sudah bisa menyimpulkan teks bacaan yang dipelajari dari segi isi dan tata bahasa serta hikmah-hikmah yang bisa diambil dari bacaan.

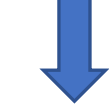

\section{MENGKOMUNIKASIKAN}

Dilakukan dengan presentasi hasil dan menulis. Peserta didik mempraktikkan percakapan di depan kelas. Membaca teks bahasa Arab di depan kelas dan menjelaskan isi dari bacaan. Mempresentasikan hasil kalimat yang telah disusun. Serta menulis dengan bahasa Arab braille tentang materi dengan susunan tata bahasa Arab yang benar kemudian dikumpulkan ke guru.

\section{Faktor pendukung dan penghambat implementasi pendekatan Saintifik bagi tunanetra di} MTs. Yaketunis

Dari hasil observasi dan wawancara ada beberapa faktor pendukung implementasi pendekatan saintifik bagi tunanetra di MTs. Yaketunis yaitu yang pertama antusias peserta didik dalam mengikuti pelajaran sehinngga peserta didik menjadi lebih tertib dan semangat mengikuti pembelajaran. Faktor pendukung yang kedua yaitu pembelajaran yang santai dan tidak menekan peserta didik, karena memang prinsip pembelajaran yang diterapkan oleh guru adalah murid senang. Dan yang terakhir adalah tersedianya buku ajar Kurikulum 2013 bagi guru sehingga memudahkan guru untuk mengolah materi dan model pembelajaran yang diterapkan sesuai Kurikulum 2013.

Faktor penghambat yang dialami dalam implementasi pendekatan saintifik adalah belum adanya buku ajar yang berbentuk braille sehingga peserta didik tidak bisa belajar mandiri. Tidak 
ALSUNIYAT: Jurnal Penelitian Bahasa, Sastra, dan Budaya Arab

ada bahan ajar bahasa Arab braille untuk belajar mandiri peserta didik tunanetra merupakan problem yang sama-sama diungkapkan oleh guru, peserta didik, dan kepala sekolah. Yang kedua yaitu kurangnya media pembelajaran untuk menunjang pembelajaran.

Solusi yang diambil guru karena tidak ada media dan bahan ajar braille adalah melaksanakan pembelajaran dengan cara mencatat dan menghafal. Dengan ada catatan membuat peserta didik bisa belajar kembali jika lupa dengan pelajaran yang sudah lewat. Selain itu, peserta didik masih ada yang bingung membaca panjang pendek tulisan arab solusi yang biasa diterapkan peserta didik adalah mencatat dengan huruf braille.

Hambatan yang terakhir dari peserta didik yaitu ada beberapa peserta didik yang menganggap pembelajaran bahasa Arab itu susah. Faktor penghambat belajar bahasa Arab juga berasal dari peserta didik sendiri. Perbedaan kemampuan peserta didik dalam pembelajaran bahasa Arab juga berpengaruh. Perbedaan ini dikarenakan perbedaan individu antar peserta didik dari jenis kelamin, penguasaan bahasa ibu, kedekatan bahasa ibu dengan bahasa Arab, motivasi belajar bahasa Arab, gaya belajar dan lain sebagainya (Nurtresnaningsih, 2018).

Faktor penghambat ini yang perlu diperhatikan. Sehingga pelaksanaan Kurikulum 2013 bisa terlaksana dengan baik. Untuk implementasi pendekatan saintifik bagi tunanetra, guru memaksimalkan fasilitas dan faktor-faktor pendukung yang ada sehingga pembelajaran dengan pendekatan saintifik bisa terlaksana dengan baik dan lancar.

\section{SIMPULAN}

Pendekatan pembelajaran yang diterapkan di MTs. Yayasan Kesejahteraan Tunanetra Yogyakarta adalah pendekatan saintifik sesuai yang dianjurkan oleh Kurikulum 2013. Proses pembelajaran memiliki lima komponen yang dilaksanakan yaitu mengamati, menanya, menalar, mengolah data, dan mengkomunikasikan hasil belajar. Perbedaan dalam implementasi pendekatan saintifik bagi tunanetra dengan peserta didik normal adalah indra yang digunakan pada proses mengamati.

Peserta didik normal melakukan pengamatan materi dengan melihat video atau bendabenda yang disajikan oleh guru tetapi peserta didik tunanetra tidak bisa menggunakan indra penglihat, proses mengamati dilakukan dengan mendengarkan, meraba, mencium atau merasa, tetapi untuk pembelajaran bahasa yang sering digunakan adalah pendengaran dan meraba. 
ALSUNIYAT: Jurnal Penelitian Bahasa, Sastra, dan Budaya Arab

Selain membedakan lagi adalah media pembelajaran bahasa Arab bagi tunanetra tidak menggunakan papan tulis dan proyektor seperti anak-anak normal. Media dan alat yang digunakan adalah buku-buku braille. Tapi yang membuat perihatin adalah belum tersedianya buku braille sebagai sumber belajar mandiri untuk peserta didik tunanetra sehingga peserta didik tunanetra tidak bergantung pada orang. Semoga dengan adanya penelitian ini bisa memberi masukan kepada pemegang kebijakan dan para ahli yang berkecimpung dalam dunia pendidikan membantu dan memperhatikan peserta didik yang memiliki kebutuhan khusus seperti tunanetra.

\section{DAFTAR PUSTAKA}

Adriyanto, F., Setiyatna, H., \& Santosa, B. (2018). Sign language for learning the pronunciation of the Qur'an An Effort to Compile and Implement a Sign Language System to Help Blind People Learn to Read the Qur'an Correctly. Advance in Social Science, Education and Humanities Research, 272, 55-58. https://doi.org/10.2991/indoeduc-18.2018.16

Budiyanto, M. A. K., Waluyo, L., \& Mokhtar, A. (2016). Implementasi pendekatan saintifik dalam pembelajaran di pendidikan dasar di Malang Implementation of Scientific Approach in Education in Primary Education in Malang. Biologi, Sains, Lingkungan, dan Pembelajaran, 13(1), 46-51.

Harimi, A. C. (2018). Strategi pembelajaran kemahiran menulis bagi peserta didik tunanetra. Kreativitas dan inovasi dalam pembelajaran bahasa Arab di Indonesia, 8, 51-56. https://doi.org/10.1017/CB09781107415324.004

Hosnan. (2014). Pendekatan saintifik dan kontekstual dalam pembelajaran abad 21. Ghalia Indonesia.

Machin, A. (2014). Implementasi pendekatan saintifik, penanaman karakter dan konservasi pada pembelajaran materi pertumbuhan. Jurnal Pendidikan IPA Indonesia, 3(1), 28-35. https://doi.org/10.15294/jpii.v3i1.2898

Majid, A., \& Rochman, C. (2015). Pendekatan ilmiah dalam implementasi kurikulum 2013. PT Remaja Rosdakarya.

Muhardi. (2004). Kontribusi pendidikan dalam meningkatkan kualitas bangsa Indonesia. MIMBAR Jurnal Sosial dan Pembangunan, 20(4), 478-492. https://doi.org/10.29313/mimbar.v20i4.153

Muryati, I. (2016). Pengelolaan dana BOS pada SD negeri di UPT pelayanan pendidikan Kecamatan 
ALSUNIYAT: Jurnal Penelitian Bahasa, Sastra, dan Budaya Arab

Moyudan Kabupaten Sleman. Jurnal Akuntabilitas Managemen Pendidikan, 4(2), 237-246. https://doi.org/10.21831/amp.v4i2.10802

Nurtresnaningsih, I. (2018). Problematika siswa dalam pembelajaran bahasa Arab serta upaya dalam menanggulanginya. Alsuniyat : Jurnal, Penelitian Bahasa, Sastra, dan Budaya Arab, 1(1), 17-29. https://doi.org/10.17509/alsuniyat.v1i1.24196

Rathomi, A. (2019). Pembelajaran bahasa Arab maharah qira'ah melalui pendekatan saintifik. Ta'dib : Jurnal Pendidikan Islam, 8(1), 558-565. https://doi.org/10.29313/tjpi.v8i1.4315

Rubini, \& Setyawan, C. E. (2019). Inclusion education: learning reading Arabic language and AlQuran for blind. AL-BIDAYAH: Jurnal Pendidikan Dasar Islam, 11(2), 330-345. https://doi.org/10.14421/al-bidayah.v11i2.348

Saputri, D. R. (2013). Proses pembelajaran seni musik bagi siswa tunanetra. HARMONI Journal of Arts Research and Education, 13(1), 37-44. https://doi.org/10.15294/harmonia.v13i1.2531

Thohari, S. (2014). Pandangan disabilitas dan aksesibilitas fasilitas publik bagi penyandang disabilitas di kota Malang. Indonesian Journal of Disability, 1(1), 27-37. 